\title{
Sublittoral seaweed communities on natural and artificial substrata in a high-latitude coral community in South Africa
}

\author{
L. Gersun, R.J . Anderson, J .R. Hart, G.W. Maneveldt and J .J . Bolton
}

\begin{abstract}
Coral mortality may result in macroalgal proliferation or a phase shift into an alga dominated state. Subtidal, high-latitude western Indian Ocean coral communities at Sodwana Bay on the KwaZulu-Natal coast, South Africa, have experienced some mortality because of warm water anomalies, storms and other causes, but the response of the macroalgae is unknown. We investigated the abundance and diversity of benthic algae on different hard natural substrata (dead digitate, brain and plate corals and beach rock) on Two-Mile Reef, Sodwana Bay. We also compared algal communities colonising ceramic, marble and pretreated ceramic tiles placed on the reef for six months. We identified 95 algae (14 Chlorophyta, 11 Phaeophyceae, 69 Rhodophyta and one cyanobacterium). Assemblages on natural and artificial substrata were dominated by the brown alga Lobophora variegata (Lamouroux) Womersley ex Oliveira and non-geniculate corallines (Rhodophyta, Corallinaceae). Cluster and ordination analyses revealed that the algae showed no affinity for particular substrata, whether natural or artificial. Algal cover was occasionally higher on rougher tiles and crustose corallines were significantly more abundant on marble than ceramic tiles. Two-Mile Reef had $23.1 \%$ dead and $48.4 \%$ live scleractinian coral cover, where dead corals were colonised indiscriminately by many small algal species, but there was no evidence of algal proliferation. The results provide a baseline for monitoring this high-latitude reef system.
\end{abstract}

\section{Introduction}

Coral reefs are among the most ecologically heterogeneous and economically important ecosystems on Earth, but are under stress from a variety of anthropogenic factors, such as overfishing, pollution and sedimentation, as well as from climate change and natural disturbances (Hughes 1994; Wilkinson 2002; Hughes et al. 2003; Pandolfi et al. 2005). Algae are rapid and efficient primary colonisers of newly available substrata on almost any part of a coral reef that has been opened by disturbances (Diaz-Pulido and McCook 2002). Past studies have shown how hurricane damage on reefs can lead to rapid macroalgal proliferation (Hughes 1994; Fong and Lirman 1995; Rogers et al. 1997) and, in severe cases, cause extensive phase shifts from coral-dominance to dominance by benthic algae (McCook 1999; Hoegh-Guldberg et al. 2007), potentially contributing to long-term reef degradation (McCook 1999). Rising ocean temperatures have triggered mass bleaching episodes that have resulted in catastrophic loss of coral cover around the world (Glynn 1993; Hoegh-Guldberg et al. 
2007). Many studies on coral bleaching describe the physiological and climatological causes of bleaching, behaviour of zooxanthellae and recovery of zooxanthellae after damage (e.g. Hoegh-Guldberg 1999). However, there has been little work focusing on algal recruitment on damaged corals that fail to recover their zooxanthellae. Work that has been conducted includes recruitment dynamics studies (Diaz-Pulido and McCook 2002; Titlyanov et al. 2008), which reported that dead coral skeletal tissue was colonised by diverse commu nities of macroalgae and concluded that macroalgae do not colonise healthy coral tissue and that algal colonisation was not the initial cause of coral tissue mortality. Successional patterns of tropical macroalgae rely upon vacant space, nutrient availability and grazing pressure. Various studies have reported the recovery of coral reef systems after a catastrophic event and the succession of algae during this process, along with succession on experimental settlement plates. In general, turf algae are among the first to colonise available space, followed by a dominance of thin and finely branched filamentous seaweeds, which at a later stage are replaced by dense growths of thick canopyforming seaweed (McManus and Polsenberg 2004; Mumby 2009). The 37-year history of the coral reef assemblages in Moorea, French Polynesia, represents one of the longestkept records of coral reef dynamics. Between 1991 and 1994, disturbances caused declines in coral cover, with consequent colonisation by algal turfs. However, Adjeroud et al. (2009) did not observe a successional sequence of algal growth, but instead the cover of turf algae decreased and returned to predisturbance levels within a decade. This result indicates that the availability of empty substratum is not sufficient to cause a persistent increase in algal cover and that other factors, such as an increase in nutrients or a reduction in grazing pressure, may be pertinent for a phase shift to macroalgal dominance (McManus and Polsenberg 2004; Mumby et al. 2005). A pattern of algal succession emerged from the extensive loss of coral cover on the Great Barrier Reef, Australia, following the massive bleaching event in 1998. Algal assemblages were initially dominated by blue-green photosynthetic bacteria, but rapidly shifted to an assemblage dominated by algal turfs, whereafter fleshy macroalgae and crustose coralline algae overgrew the turfs during later stages of the succession (Diaz-Pulido and McCook 2002). Fluctuating weather conditions throughout the year strongly affect the abundance of macroalgae in tropical regions; for example, lower temperatures during the rainy season can cause a significant increase of algal biomass. Ateweberhan et al. (2006) carried out an extensive overview of seasonality of four major functional groups of coral reef macroalgae (canopy, foliose, turf and crustose corallines) in the southern Red Sea. They observed strong seasonal shifts in macroalgal biomass, although seasonal variation differed among groups. Canopy and foliose macroalgae were highly seasonal, whereas turf and crustose coralline algae displayed much less seasonal variability. The settlement and recruitment of algal propagules onto reef communities require suitable hard substrata and the ability to compete with organisms already present (Worm and Chapman 1998). Surface texture, material and chemical composition have been shown to influence strongly the settlement and survival of algal recruits. Diaz-Pulido and McCook (2002) reported that algal colonisation on clay settlement tiles differed markedly from that on dead coral skeleton and their subsequent study (Diaz-Pulido and MoCook 2004) found that natural substrata supported more mature assemblages than artificial substrata. In addition, the species composition of algal assemblages differed according to the severity of bleaching damage to 
the corals: species composition on severely bleached corals was in a more developed successional stage than that on less-bleached corals. The inshore, high-latitude coral communities of southern Africa suffered negligible impacts during past mass bleaching events, but the most recent bleaching in 2005 in southern Africa, when a warm-water anomaly affected much of the southern Indian Ocean, resulted in more extensive damage to coral on South African reefs (McClanahan et al. 2007; Celliers and Schleyer 2008). Although some information on subtidal macroalgal turf communities in Sodwana Bay is available (Anderson et al. 2005), there is no information on the distribution ofmacroalgal assemblages on the different types of hard substrata, including dead corals. There is also no information on possible seasonal changes in algal community structure. Although anecdotal reports received from divers by RJ A suggested extensive seaweed colonisation of dead coral on TwoMile Reef, this has never been formally investigated. This study aimed to investigate algal colonisation on the different types of hard substrata (including different taxa of dead coral) that are present on the reefs. We also explored the relationship between abiotic properties of artificial substrata (i.e. surface texture and material) and algal recruitment. Three hypotheses were tested: (i) different natural hard substrata support different algal commu nities; (ii) communities colonising different types of artificial substrata (ceramic tiles, marble tiles and pretreated ceramic tiles) would differ; and (iii) algal communities differ between autumn and spring (seasonal differentiation).

\section{Material and methods Data collection}

The study was carried out on Two-Mile Reef $\left(27^{\circ} 31^{\prime} 29^{\prime \prime} \mathrm{S}, 32^{\circ} 40^{\prime} 37^{\prime \prime} \mathrm{E}\right)$, which is located in the central Maputaland reef complex at Sodwana Bay (KwaZulu-Natal, South Africa; Figure 1). Two-Mile Reef is a highly rugose patch-reef system, with reef ridges, reef slopes and gullies (Ramsay and Mason 1990; J ordan and Samways 2001). The reef, lying $1 \mathrm{~km}$ offshore, is approximately $1.8 \mathrm{~km}$ long and $900 \mathrm{~m}$ wide and is always submerged (Ramsay and Mason 1990; Celliers and Schleyer 2008). The water depth on the reef varies between 6 and $10 \mathrm{~m}$ on its shallowest pinnacles, to 14-19 m on extensive deep subtidal reef flats and 24-27 m at the edge of the fore-reef (Celliers and Schleyer 2002). Study sites were scattered on the reef at various depths ranging from $8 \mathrm{~m}$ to $19 \mathrm{~m}$. Seawater tempera ture was measured with a Starmon Mini (Star-Oddi, Iceland) recorder at $12 \mathrm{~m}$ depth on the reef. All fieldwork was carried out on 1-4 March and 6- 9 September 2010 by divers using SCUBA. Because algal communities were being studied, divers placed quadrats at least $1 \mathrm{~m}$ apart in a stratified random pattern (fortyfive $10 \mathrm{~cm} \times 10 \mathrm{~cm}$ wire quadrats per sampling period) on substrata bearing seaweeds, rather than randomly over the whole substratum of the reef. The same sites (within approximately $50 \mathrm{~m}$ ) were sampled in March and September. All the visible macroalgae within each quadrat, except highly adherent crustose forms, were scraped off the dead coral using a paint scraper and collected in fine-mesh bags. The substratum directly under each of the quadrats was then recorded and was visually classified into one of four categories: digitate coral, plate coral, brain coral and 'hard (bare) substratum'. In instances where it proved difficult or impossible to scrape the surface effectively, chunks of the substratum were broken off using a chisel and hammer and taken to the field laboratory.

Estimates of the relative cover of different types of substrata were made using line-point 
intercept (LPI) methods along 20-m transect lines, which were placed haphazardly at approximately right angles to the reef axis. A diver swam along the transect line and recorded the benthic category directly below the transect line at every $0.25-\mathrm{m}$ interval (80 points/transect; four transects per sampling period). Benthic categories used were: live coral, dead coral, macroalgae (including non-geniculate coralline algae), sand, hard (bare) substratum and sponge.

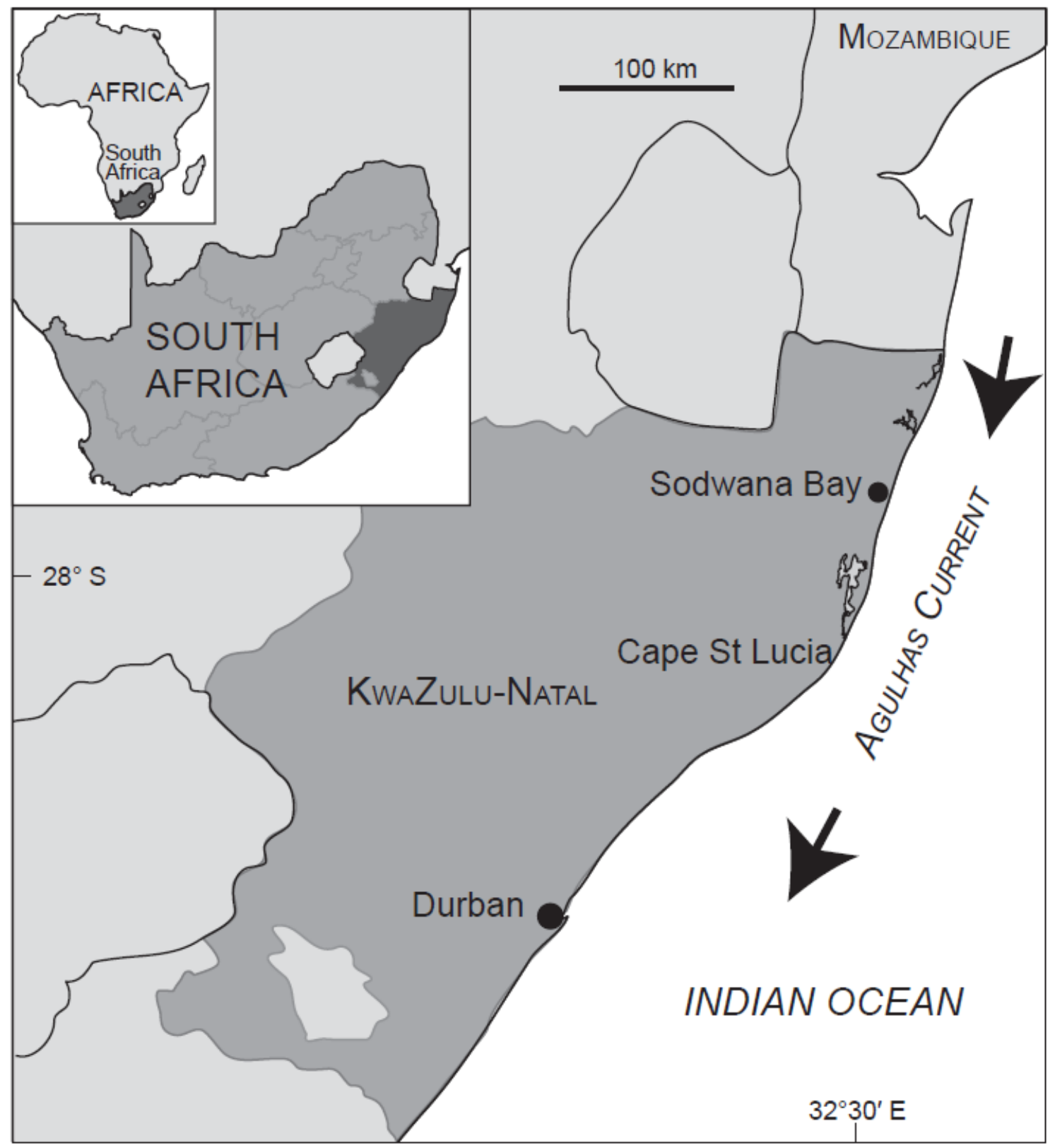

Figure 1: Map of KwaZulu-Natal, South Africa, showing the location of Sodwana Bay 
In the field laboratory, each quadrat sample was placed in a sorting tray and covered with seawater. All macroalgae Dead coral was defined as a substratum that maintained the full structural integrity of coral, but had no live coral tissue, whereas bare consolidated surfaces on the reef that could from each sample (quadrat) were sorted into separate species or genera (provisional identifications) and an initial visual estimate of cover-abundance was made. A modified Braun-Blanquet scale (Lepš and Hadincová 1992) was used to assign a cover-abundance value to each species within each quadrat: 0 - no cover; 1 - rare $(<5 \%$ cover); 2 - occasional (5- 25\% cover); 3 - common (25- 50\% cover); 4 - abundant (50- 75\% cover); and 5 - dominant ( $>75 \%$ cover). In cases where whole chunks of substratum were broken off, an initial estimate of cover was made, followed by subsequent sorting to species or generic level. Seaweeds were preserved in 5\% formalin in seawater for subsequent identification, where possible to species level. When necessary, specimens were stained with fast green and mounted in corn syrup on microscope slides (Tsuda and Abbott 1985) for later identification and for cross-referencing during sorting of subsequent samples. Seaweeds were identified using morphological descriptions according to J aasund (1976), Stegenga et al. (1997), De Clerck et al. (2005) and Oliveira et al. (2005) and/or compared to appropriate material and other published literature. Identification procedures for non-geniculate coralline algae followed Maneveldt and van der Merwe (2012).

\section{Artificial settlement surfaces: experimental design}

To test the hypothesis that seaweed recruitment would differ on different artificial settlement surfaces, we quantified algal colonisation on settlement tiles used by Hart (2012) to assess how coral settlement varies on different artificial settlement surfaces. Three replicate concrete Y-frames (Figure 2), with 15 settlement tiles attached to each, were positioned 5- 15 $\mathrm{m}$ apart from each other on flat reef areas at three study sites on Two-Mile Reef (Figure 2). 


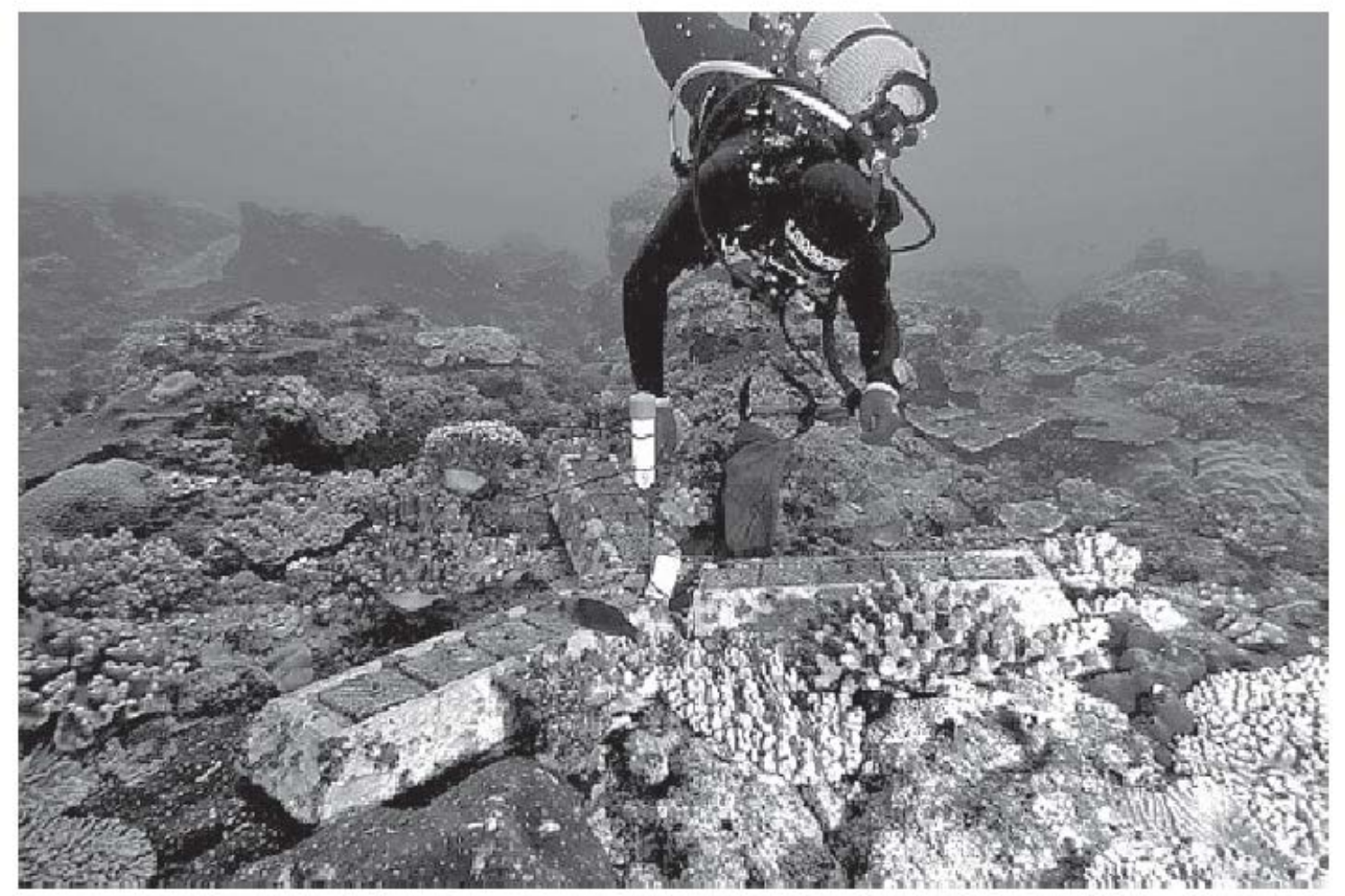

Figure 2: An example of a Y-frame to which the three types of tiles were attached and general appearance of the reef (photo: C Floros)

Each monitoring site was similar in depth and topography and was selected in a north-south direction on the reef. The northern site was the deepest (15-17 m), characterised by flat topography with few gullies. The central (12-15 m) and southern sites (9-12 m) were in an area of varied topography with sharp drop-offs into sand gullies. Three types of artificial substratum were used: unglazed ceramic tiles, marble tiles and ceramic tiles preconditioned with crustose coralline algae (ceramic tiles were preconditioned for two months in an aquarium where Mesophyllum funafutiense (Foslie) Verheij in Verheij \& Prud'homme van Reine was prolific). All tiles were $9.7 \mathrm{~cm} \times 9.7 \mathrm{~cm} \times 1 \mathrm{~cm}$ and had a 6 - $\mathrm{mm}$ hole drilled in their centre to enable horizontal attachment onto the frames. The weight of each frame $(75 \mathrm{~kg})$ and its flat, three-armed shape provided sufficient anchorage and stability for the settlement tiles during major turbulence on the reef. Five replicates of each tile type were anchored onto each Y-frame, in a stratified sampling design that mixed tile types on each arm. The tiles were left on the reef for six months (October 2009-April 2010), then retrieved and preserved in 4\% formalin seawater solution for storage prior to examination in the laboratory. The upper surface of each tile was examined for fleshy algae and non-geniculate coralline algae using a Zeiss Stemi stereo dissection microscope at $10 \times$ magnification. The Braun-Blanquet scale was used to assign a cover-abundance value to the macroalgal recruits (including non geniculate coralline algae) on the tiles, using the same categories as for the algae on natural substrata. Subsequently, the macroalgae were scraped off the tile with a dull surgical blade; wherever possible, the algal material obtained was identified to species. 


\section{Statistical analyses}

Data were analysed using Community Analysis Package 4.0 (Pisces Conservation Limited). The seaweed community data were subjected to multivariate analysis (ordination by detrended correspondence analysis [DECORANA], using the option to downweight rare species) and cluster analysis (complete linkage, Bray-Curtis similarity coefficient), to show how substrata and seasons cluster with respect to their seaweed flora. To assess the adequacy of sampling, species accumulation curves were generated in PRIMER 6 (PRIMER-E Ltd), where a first-order jackknife (jackknife 1), a species richness estimator, was calculated. Using Statistica 11, a Kruskal-Wallis non-parametric test was used to detect significant differences in macroalgal abundance among different natural substrata (digitate coral, brain coral, plate coral and hard substratum) and likewise among the tile treatments (marble, ceramic and treated ceramic tiles). Differences among substrata/ treatments were considered significant if $\mathrm{p}<0.05$. Where the results of Kruskal-Wallis tests were significant, pairwise MannWhitney tests between the substrata/treatments were performed with significance levels adjusted to account for multiple comparisons (Bonferroni correction, $\alpha=0.017$ ).

\section{Results}

\section{Sea temperature}

Monthly mean temperature reached a maximum of $26-27^{\circ} \mathrm{C}$ during the summer with a minimum monthly mean temperature of $22.4{ }^{\circ} \mathrm{C}$ in winter (Figure 3). The lowest temperature recorded was $20.2{ }^{\circ} \mathrm{C}$ on 2 August 2010 and the highest $\left(27.8{ }^{\circ} \mathrm{C}\right)$ on 23 February 2010. There was a notable drop in temperature during February, to a minimum of $21.6^{\circ} \mathrm{C}$.

\section{Composition of benthic categories}

Benthic cover was dominated by live scleractinian corals, comprising $48.4 \%$ of the total cover. Dead corals occupied much less space (23.1\% of total benthic cover), followed by hard (bare) substratum (20.9\%). Non-geniculate coralline and fleshy macroalgae (5\%) exceeded sponges and other invertebrate groups, the latter comprising $<3 \%$ of the cover.

\section{Species accumulation curves}

On all four natural substratum types on which seaweeds were found, species richness increased as a function of sampling effort. Observed species accumulation and jackknife 1 estimated curves (not shown) did not plateau on any substratum type, indicating that the macroalgal species identified comprise only a portion of the total diversity occurring on the different substrata. Based on jackknife 1 estimates, the recorded vs expected numbers of species for the various substratum types were: brain coral $=28$ vs 43 , plate coral $=31$ vs 51 , digitate coral $=41$ vs 65 and hard substrata $=54$ vs 81 . A further species accumulation curve (not shown), based on the cumulative number of species plotted against the overall number of samples collected, approached an asymptote, indicating that the macroalgae found on Two-Mile Reef were sufficiently well-sampled to capture most of the species diversity: the estimate curve predicted 123 species, whereas the observed curve recorded 95 species. 


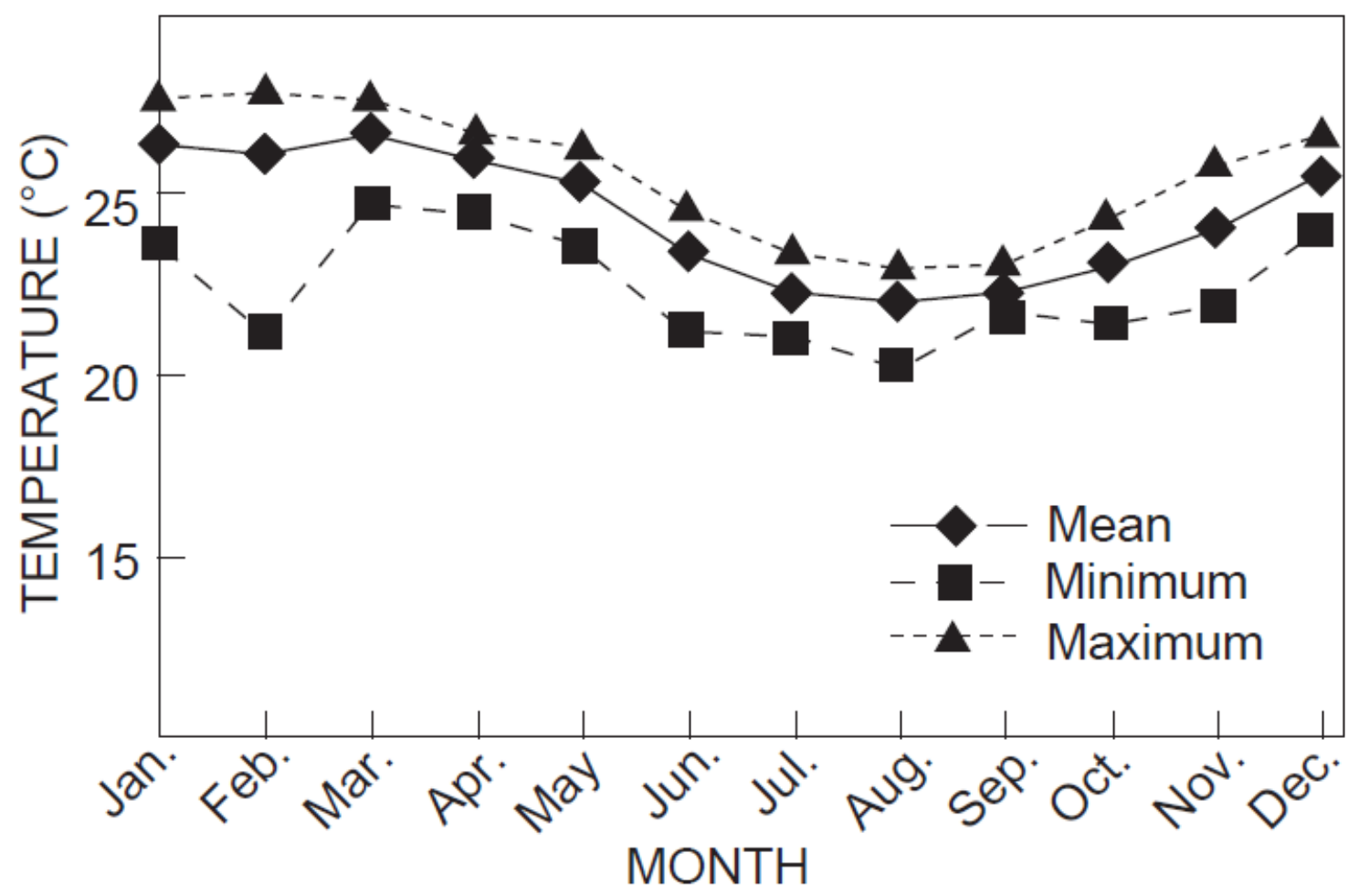

Figure 3: Seawater temperatures at 12-m depth on Two-Mile Reef, Sodwana Bay, January-December 2010. Solid line shows monthly mean temperature, broken lines show the highest and lowest absolute temperatures measured during each month

\section{Algal colonisation on natural substrata}

In total, 95 taxa of subtidal seaweeds were recorded in the 90 sample quadrats, including 14 Chlorophyta, 11 Phaeophyceae, 69 Rhodophyta and one cyanobacterium (Table 1). In all quadrats, the greatest number of species belonged to the red algae (Table 1) and these were mostly small turf-forming species. Rhodophyta that were present and relatively common in March and September were: Hypnea spinella, Pterocladiella caerulescens and Herposiphonia tenella. The brown alga Lobophora variegata was found throughout the sampling periods (66 out of 89 quadrats), either as a low turf component or with larger conspicuous blades. Three species were recorded for the first time in South African waters: Codium dwarkense (Chlorophyta, Codiaceae), Lithophyllum cuneatum and Pneophyllum sp. (both Rhodophyta, Corallinaceae) (Table 1).

\section{Seasonal variability}

Ordination of the species' Braun-Blanquet data in all 90 quadrats (correspondence analysis, not shown) produced a highly skewed pattern with Quadrat 43 (March) completely separate on the x-axis and forcing all of the 89 other quadrats into a small group. Quadrat 43 was very unusual in that it contained only one species of alga (Champia sp.). It was accordingly excluded from subsequent ordinations. The Bray-Curtis cluster analysis (not shown) of the 89 remaining quadrats revealed no seasonal clustering in the composition and abundance of 
algal communities. The results were similar for the ordination analysis where the DECORANA (Figure 4) failed to display any distinct pattern that related to seasonal change. As a result, data for the two sampling periods were combined for many of the subsequent analyses.

\section{Overall patterns of algal communities}

The brown foliose alga Lobophora variegata was the most common macroalga encountered in the quadrat surveys and was found in $73 \%$ of all the samples (Figure 5) from Two-Mile Reef. It was usually abundant across all substratum types in March and September and it had the highest mean Braun-Blanquet score (2.2) of any of the taxa (Figure 6). Of the other macroalgae, non-geniculate crustose coralline algae (as a combined form) were the next most common 'taxon,' occurring in 63\% of all quadrats with a mean Braun-Blanquet score of 2.07. Overall among the algae, six species were present at a frequency $>20 \%$ and a further two species $>50 \%$ (Figure 5), whereas 67 species showed a frequency $<5 \%$. Several species were considered 'rare' according to their Braun-Blanquet cover score ( $<5 \%$ cover), including Halymenia durvillei, Jania intermedia, Platysiphonia delicata, Turbinaria ornata, Wurdemannia miniata and Codium acuminatum. 
Table 1: Seaweeds (including non-geniculate coralline algae) collected at Two-Mile Reef, Sodwana Bay. Species marked with an asterisk are new records for South Africa. 'March' and 'September' refer to natural substrata and 'Tiles' to artificial substrata. $1=$ present, $0=$ absent

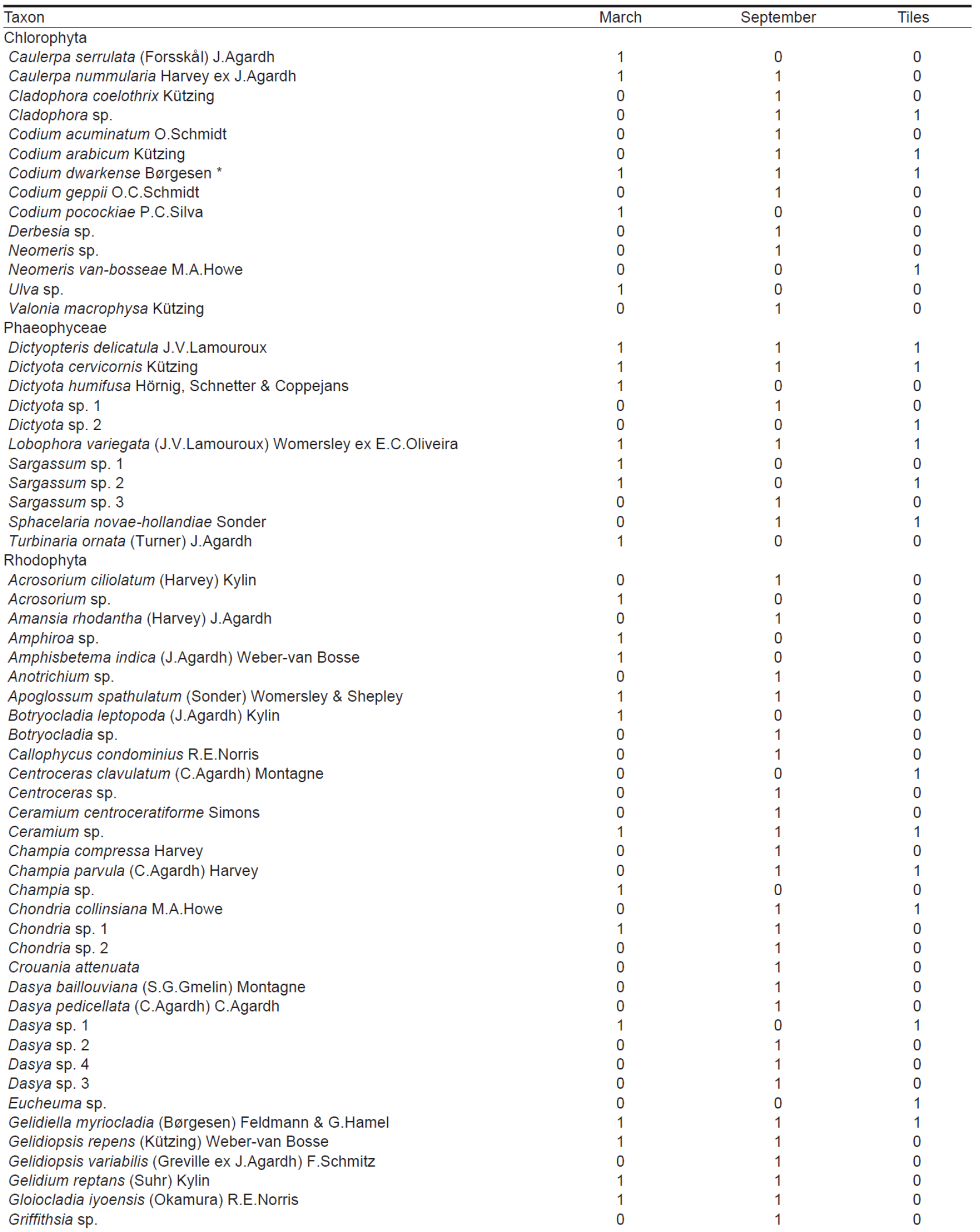


Table 1: (cont.)

\begin{tabular}{|c|c|c|c|}
\hline Taxon & March & September & Tiles \\
\hline Griffithsia weber-vanbosseae Børgesen & 0 & 1 & 0 \\
\hline Halichrysis coalescens (Farlow) R.E.Norris \& A.J.K.Millar & 1 & 1 & 0 \\
\hline Halymenia durvillei Bory de Saint-Vincent & 0 & 1 & 1 \\
\hline Herposiphonia tenella (C.Agardh) Ambronn & 1 & 1 & 1 \\
\hline Heterosiphonia wurdemannii (J.Bailey ex Harvey) Falkenberg & 1 & 1 & 0 \\
\hline Hydrolithon farinosum (J.V.Lamouroux) D.Penrose \& Y.M.Chamberlain & 0 & 1 & 0 \\
\hline Hydrolithon pellire Y.M.Chamberlain \& R.E.Norris & 1 & 0 & 0 \\
\hline Hypnea sp. 1 & 1 & 0 & 0 \\
\hline Hypnea sp. 2 & 1 & 0 & 0 \\
\hline Hypnea spinella (C.Agardh) Kützing & 1 & 1 & 1 \\
\hline Jania intermedia (Kützing) P.C.Silva & 0 & 1 & 0 \\
\hline Jania pumila J.V.Lamouroux & 0 & 1 & 1 \\
\hline Jania sp. & 1 & 0 & 0 \\
\hline Laurencia sp. 1 & 1 & 1 & 1 \\
\hline Laurencia sp. 2 & 0 & 1 & 0 \\
\hline Lithophyllum acrocamptum Heydrich & 0 & 1 & 0 \\
\hline Lithophyllum cuneatum Keats * & 1 & 1 & 0 \\
\hline Lithothamnion muelleri Lenormand ex Rosanoff & 1 & 0 & 0 \\
\hline Martensia elegans Hering & 0 & 1 & 0 \\
\hline Neogoniolithon brassica-florida (Harvey) Setchell \& L.R.Mason & 1 & 1 & 0 \\
\hline Platysiphonia delicata (Clemente) Cremades & 1 & 0 & 0 \\
\hline Plocamium beckeri F.Schmitz ex Simons & 0 & 1 & 0 \\
\hline Plocamium sp. & 0 & 1 & 0 \\
\hline Pneophyllum sp.* & 0 & 1 & 0 \\
\hline Porolithon onkodes (Heydrich) D.Penrose \& Woelkerling & 1 & 1 & 0 \\
\hline Polysiphonia coacta C.K.Tseng & 0 & 1 & 1 \\
\hline Polysiphonia ferulacea Suhr ex J.Agardh & 0 & 1 & 0 \\
\hline Pterocladiella caerulescens (Kützing) Santelices \& Hommersand & 1 & 1 & 1 \\
\hline Ptilothamnion cladophorae (Yamada \& T.Tanaka) G.Feldmann-Mazoyer & 0 & 1 & 0 \\
\hline Rhodymenia sp. & 0 & 1 & 0 \\
\hline Spongites yendoi (Foslie) Y.M.Chamberlain & 1 & 1 & 0 \\
\hline Tiffaniella sp. & 0 & 1 & 0 \\
\hline Tolypiocladia calodictyon (Harvey ex Kützing) P.C.Silva & 1 & 0 & 0 \\
\hline Wrangelia penicillata (C.Agardh) C.Agardh & 1 & 0 & 0 \\
\hline Wurdemannia miniata (Sprengel) Feldmann \& G.Hamel & 0 & 1 & 0 \\
\hline \multicolumn{4}{|l|}{ Cyanophyceae } \\
\hline Lyngbya sp. & 1 & 0 & 1 \\
\hline
\end{tabular}




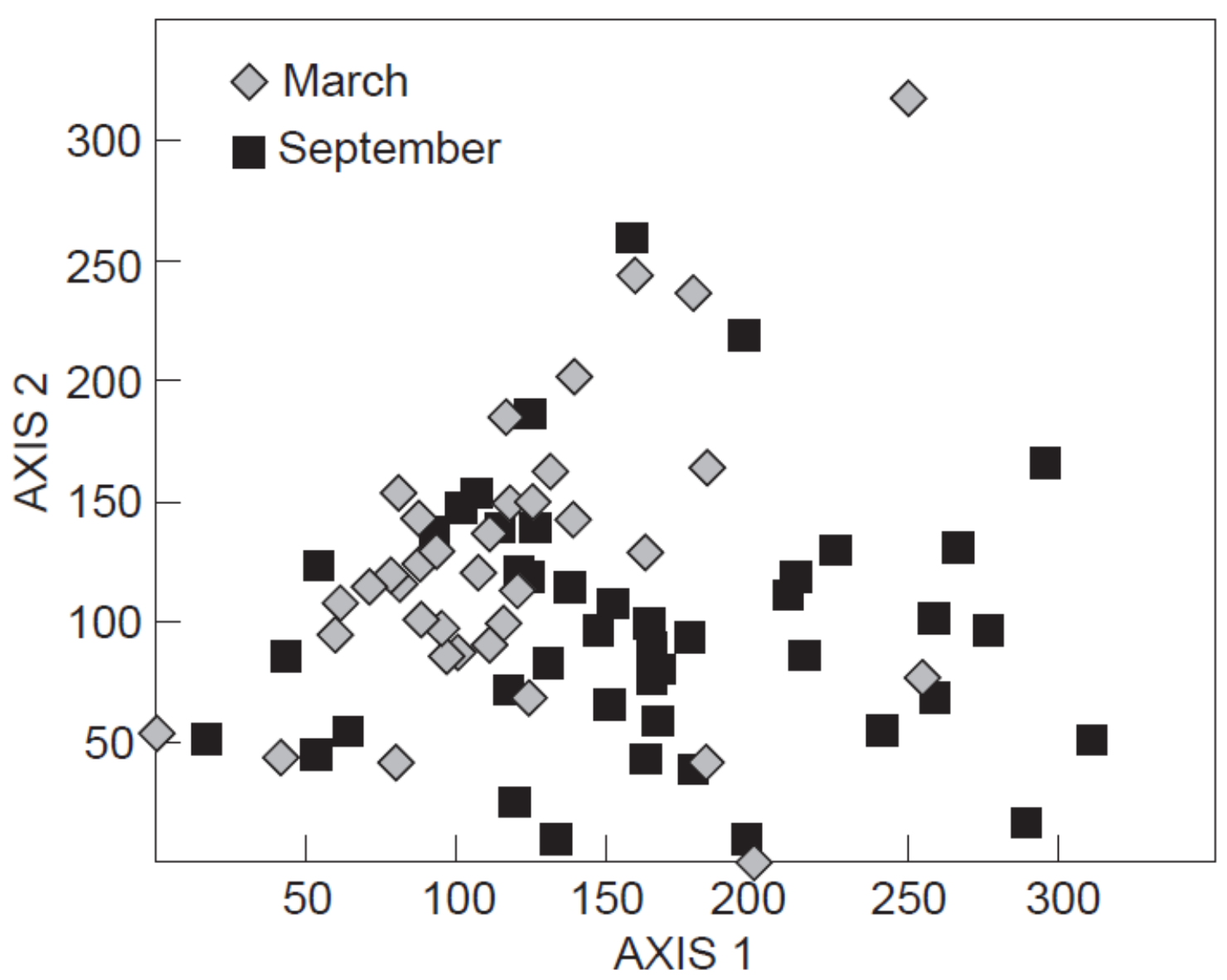

Figure 4: DECORANA analysis showing similarity between samples (quadrats), based on species' Braun-Blanquet cover values (excluding Quadrat 43) in March and September 2010. Each point represents a single quadrat (eigenvalues: Axis $1=0.344$, Axis $2=0.294$ )

\section{Community variation on different substrata}

There was no detectable clustering of substratum types according to the cover abundance of community assemblages on them (Bray-Curtis analysis, not shown). This result was supported by the DECORANA ordination analysis (Figure 7) of the cover abundance of algal species. Crustose coralline algae and L. variegata comprised most of the macroalgal cover on each natural substratum type with other algae patchy, scattered or rare. Lobophora variegata was present in almost all the quadrats and had the highest frequency value of all the fleshy macroalgae (91.7\%; Table 2). However, cover abundance of L. variegate showed no statistical difference among the substratum types (Kruskal- Wallis: $\mathrm{H}(3, \mathrm{n}=90)=5.05$; $\mathrm{p}$ $=0.14$ ). 


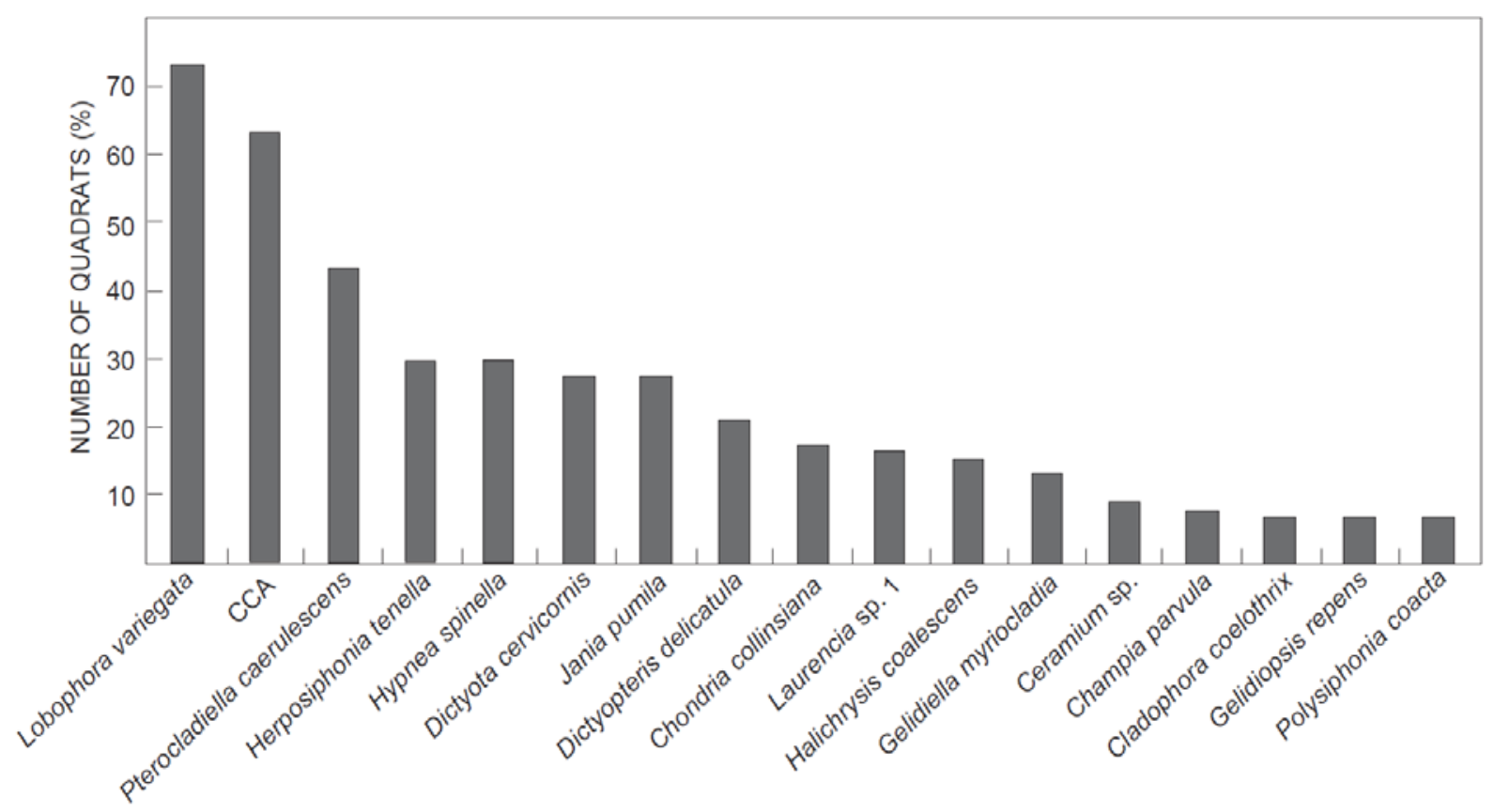

Figure 5: Overall percentage frequency for dominant taxa (mean cover $>6 \%$ ), including crustose coralline algae (CCA), in March and September 2010

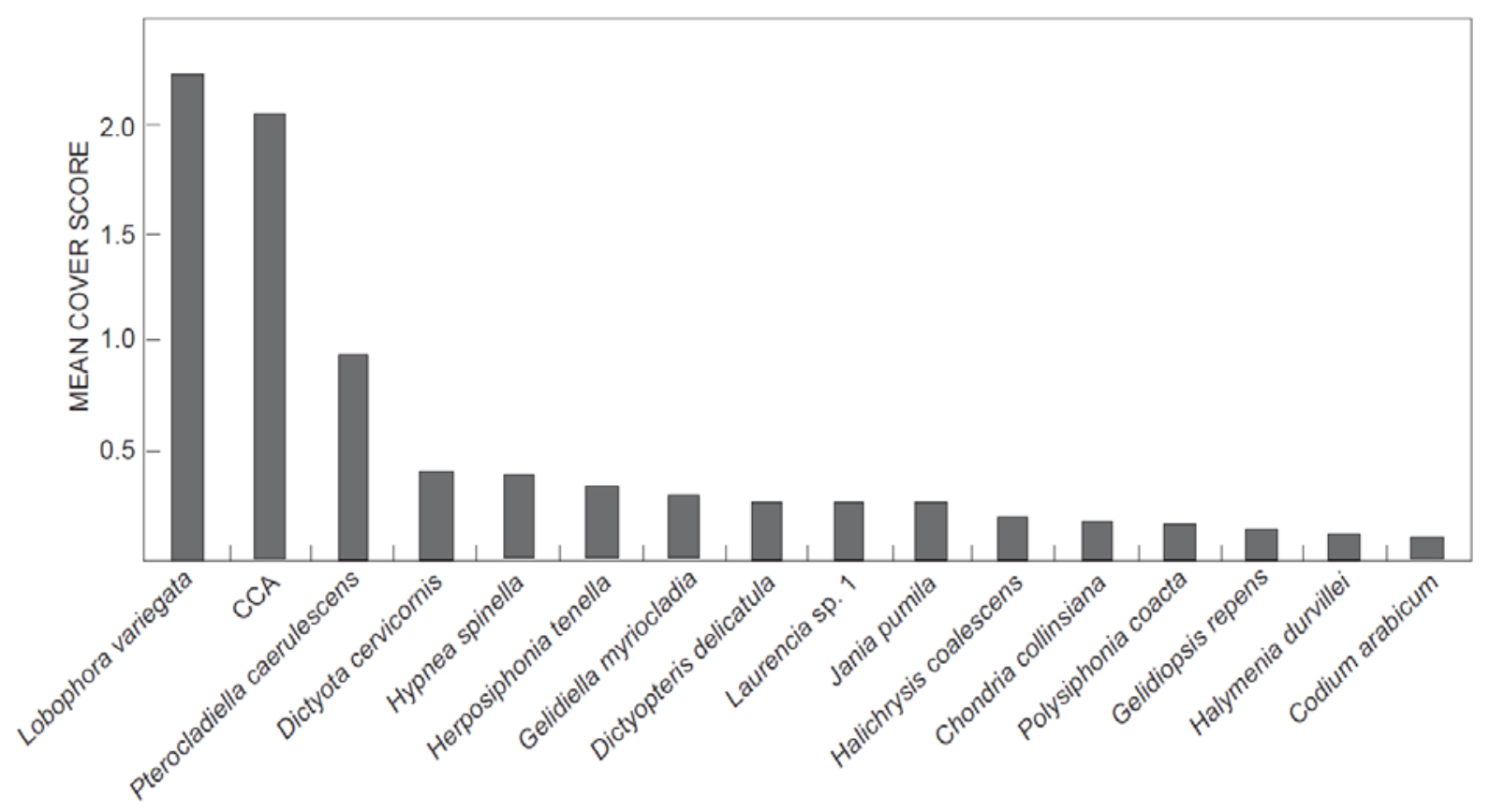

Figure 6: Overall mean Braun-Blanquet cover scores for dominant taxa (mean cover score $>0.1$ ), including crustose coralline algae (CCA), in March and September 2010 


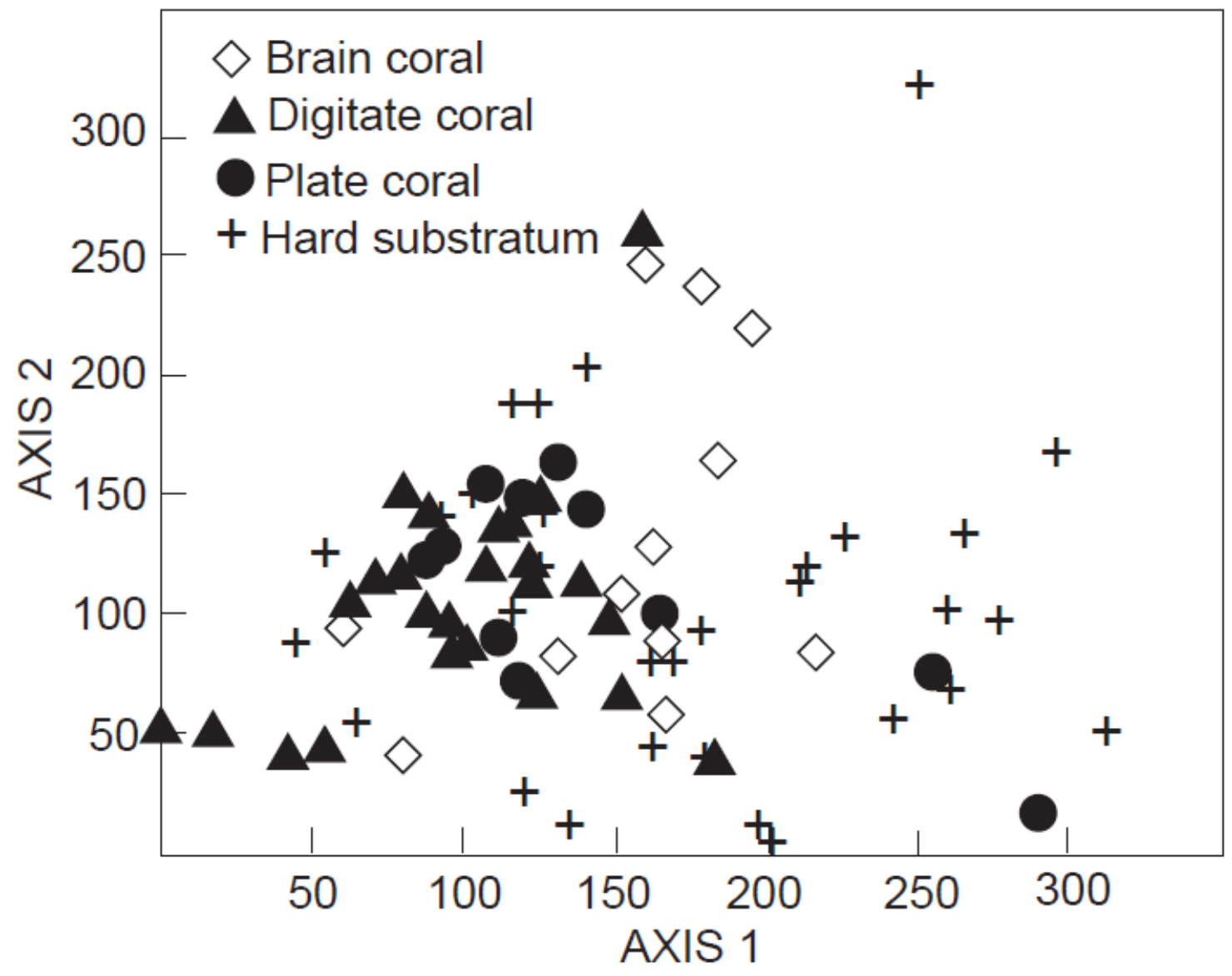

Figure 7: DECORANA analysis showing similarity between samples (quadrats) based on overall species' Braun-Blanquet cover values on different substrata (excluding Quadrat 43). Each point represents a single quadrat (eigenvalues: Axis $1=0.344$, Axis $2=0.294$ )

Table 2: Percentage frequency of dominant macroalgal species collected on each substratum type (see Material and methods for details) for March and September 2010, combined

Substratum type

Algal taxon

Brain Digitate Plate Hard

coral coral coral substratum

Lobophora variegata

Crustose coralline algae

Pterocladiella caerulescens

91.7

76.0

75.0

63.4

66.7

92.0

50.0

48.8

Herposiphonia tenella

66.7

24.0

56.1

Hypnea spinella

41.7

28.0

25.0

29.3

Dictyota cervicornis

41.7

16.0

16.7

31.7

58.3

32.0

25.0

33.3

12.0

25.0

14.6

Jania pumila

16.7

36.0

8.3

36.6

Dictyopteris delicatula 
Pterocladiella caerulescens, a common turf alga, displayed the highest frequency of all turf taxa found on hard substratum (Table 2). There was a significant difference in $\mathrm{P}$. caerulescens abundance between brain and digitate coral (Kruskal-Wallis: $\mathrm{H}(3, \mathrm{n}=90)=$ 11.33; $\mathrm{p}=0.01$; post hoc Mann- Whitney U-test: $\mathrm{U}=74 ; \mathrm{p}<0.01$ ), but it was most often observed distributed in small patches across the different substrata. Crustose coralline algae were the most abundant taxa on digitate coral, being recorded on $92 \%$ of these corals during the study (Table 2). Significant differences in cover were evident between digitate and plate corals $(\mathrm{H}(3, \mathrm{n}=90)=17.75 ; \mathrm{p}<0.001 ; \mathrm{U}=43.5 ; \mathrm{p}<0.001)$ and between digitate coral and hard substratum $(\mathrm{H}(3, \mathrm{n}=90)=17.75 ; \mathrm{p}<0.001 ; \mathrm{U}=242.5 ; \mathrm{p}<0.001)$. Macroalgae rarely had mean cover scores $>2$, indicating they rarely covered more than $25 \%$ of a quadrat, but occas ionally L. variegata or crustose coralline algae were found to cover most of a quadrat (Table 3). The high SD values indicate extreme patchiness in the distribution of almost all taxa.

\section{Algal colonisation on artificial substrata}

There was no detectable clustering of the macroalgal communities on the different tile types (Bray-Curtis analysis; results not shown). The results were similar for the ordination analysis where the DECORANA (Figure 8) failed to display any major separation between tile types based on their algal assemblages. In total, 24 taxa were identified growing on artificial settlement tiles, comprising 4 Chlorophyta, 6 Phaeophyceae and 14 Rhodophyta (Table 1). Crustose coralline algae were frequently found with high abundance across all tile types, with the highest mean Braun-Blanquet score (3.05) of any of the taxa (Table 4) and at least one species of this algal group on each tile (Figure 9). Among the other taxa, the brown seaweed L. variegata was the most common fleshy macroalga found on the tiles, occurring on $84 \%$ of the 135 tiles (Figure 9) with a mean Braun-Blanquet score of 2.25 (Table 4). Other species with less cover, but with relatively high frequency ( $>10 \%)$, were: Dictyota sp. 1, Sphacelaria novae-hollandiae, H. tenella, H. spinella and Chondria collinsiana (Figure 9; Table 4). Of the remaining macroalgal species in Table 4 , most had low mean cover scores (seldom $>1$ ), indicating they rarely covered more than $5 \%$ of a tile, but frequently $\mathrm{L}$. variegata and crustose coralline algae were observed to cover the majority of a tile. The overall macroalgal settlement on the tiles did not differ markedly among the three tile types. At the end of the 6month experiment, crustose coralline algae were found to have settled on every tile tested, regardless of treatment or material (Figure 10). Additionally, all three tile types supported a high frequency and abundance of L. variegata: frequency ranged between $88.9 \%$ on treated tiles and $80 \%$ on marble tiles (Figure 10) and mean cover scores between 2.38 (SD 1.40) on treated tiles and 2.09 (SD 1.49) on marble tiles (Table 4). In contrast, $\mathrm{H}$. tenella, H. spinella and C. collinsiana were most often distributed in small patches with low cover abundance scores (Table 4). Cover values were compared among the pretreated ceramic, marble and ceramic tiles. These data did not have homogeneous variances and were therefore analysed using Kruskal-Wallis tests. Lobophora variegata was observed overgrowing the majority of tiles during the study. There was no significant difference in the abundance of L. variegate among tiles types $(\mathrm{H}(2, \mathrm{n}=135)=1.05 ; \mathrm{p}=0.09$; Table 4$)$. In contrast, there was a significant difference in crustose coralline abundance between ceramic and marble tile types $(\mathrm{H}(2, \mathrm{n}=135)=20.06 ; \mathrm{p}<0.001 ; \mathrm{U}=494.5 ; \mathrm{p}<0.001)$. 


\section{Discussion \\ Sea temperature}

Table 3: Mean Braun-Blanquet cover scores of dominant macroalgal species on each substratum type for March and September 2010 combined and significance of differences between substratum types

\begin{tabular}{lccccc}
\hline Algal taxon & $\begin{array}{c}\text { Brain } \\
\text { coral (SD) }\end{array}$ & $\begin{array}{c}\text { Digitate } \\
\text { coral (SD) }\end{array}$ & $\begin{array}{c}\text { Plate coral } \\
(\mathrm{SD})\end{array}$ & $\begin{array}{c}\text { Hard } \\
\text { substratum (SD) }\end{array}$ & $\begin{array}{c}\text { Significance } \\
\text { Lobophora variegata }\end{array}$ \\
Crustose coralline algae & $2.33(1.07)$ & $2.44(1.73)$ & $3.08(2.07)$ & $1.88(1.79)$ & $\mathrm{ns}$ \\
Pterocladiella caerulescens & $2.33(2.06)$ & $3.28(1.51)$ & $1.08(1.24)$ & $1.54(1.80)$ & $*$ \\
Herposiphonia tenella & $1.58(1.62)$ & $0.32(0.63)$ & $0.50(1.00)$ & $1.30(1.65)$ & $*$ \\
Hypnea spinella & $0.58(0.79)$ & $0.28(0.46)$ & $0.17(0.39)$ & $0.33(0.53)$ & $\mathrm{ns}$ \\
Dictyota cervicornis & $0.50(0.67)$ & $0.32(0.85)$ & $0.25(0.45)$ & $0.45(0.78)$ & $\mathrm{ns}$ \\
Jania pumila & $0.67(0.65)$ & $0.68(1.11)$ & $0.33(0.65)$ & $0.18(0.45)$ & $\mathrm{ns}$ \\
Dictyopteris delicatula & $0.33(0.49)$ & $0.12(0.33)$ & $0.08(0.29)$ & $0.38(0.49)$ & $\mathrm{ns}$ \\
\hline
\end{tabular}

${ }^{*}=p<0.001 ; \mathrm{ns}=$ not significant

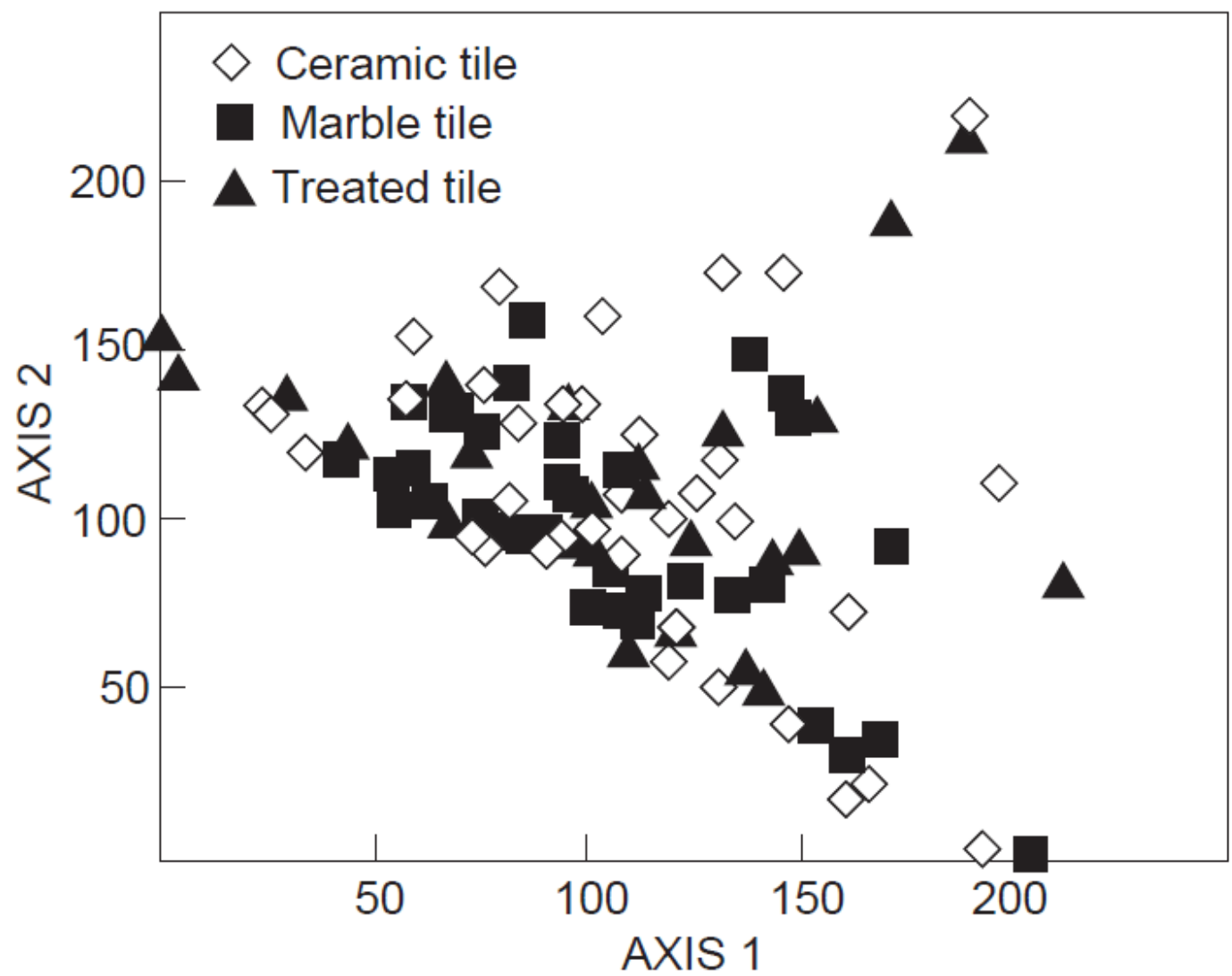

Figure 8: DECORANA analysis of tile types (ceramic, marble and treated), based on the macroalgae that occurred on them (eigenvalues: Axis $1=0.239$, Axis $2=0.178$ )

The measurements collected over a year in this study gave a seasonal temperature curve almost identical in shape to those of Schleyer (1999) and Anderson et al. (2005), including an annual cold event in February (the height of summer). This cold spike is attributed to smallscale localised upwelling of deep, cooler water (Ramsay et al. 1989), which is suggested to 
protect Sodwana Bay reefs to some extent from excessive temperatures and coral bleaching (Riegl and Piller 2003; Roberts et al. 2006). The minimum monthly mean seawater temperature is above the $20{ }^{\circ} \mathrm{C}$ minimum considered to indicate a tropical biogeographical region (Lüning 1990). The means of even the lowest temperatures recorded during each month never fell below $20{ }^{\circ} \mathrm{C}$, indicating that there are possibly very few instances when cooler water might inhibit the growth or reproduction of tropical algal species. Previous studies of seaweed communities at Sodwana and in northern KwaZulu-Natal confirm the dominance of tropical elements in the flora (e.g. Bolton et al. 2004; Anderson et al. 2005).

\section{Composition of hard substrata}

High-latitude coral reefs are typically characterised by relatively low coral cover and high abundance of fleshy macroalgae (Harriott and Banks 2002; Vroom and Braun 2010). This study revealed that the live coral cover on Two-Mile Reef, one of Africa's southernmost coral communities, was higher (overall mean $=48.1 \%$ ) than most other high-latitude reefs (c. 3.9 25.3\%; Tribble and Randall 1986; Harriott and Banks 2002; Vroom and Braun 2010) and broadly comparable to lower latitude reefs of the Great Barrier Reef, where mean coral cover typically ranges from $18.3 \%$ to $27.0 \%$ on inshore reefs and from $30.7 \%$ to $33.6 \%$ on offshore reefs (Wismer et al. 2009; Emslie et al. 2010). Estimates of hard coral cover (as a percentage of total benthic cover) on Sodwana reefs vary considerably. Riegl et al. (1995) and Riegl and Riegl (1996) reported values around $22.5 \%$ for Two-Mile Reef, Schleyer et al. (2008) reported averages around 10-12\% at Nine-Mile Reef and Celliers and Schleyer (2008) reported values of $29 \%$ for Two-Mile Reef. Our value of $48.4 \%$ is consequently very high, but similar to that of 48.8\% reported for Four-Mile Reef by Celliers and Schleyer (2008). Although this might indicate that Two-Mile Reef was in good condition at the time we sampled, we suggest that such comparisons should be treated with caution, as differences between methods (point-intercept vs photographic quadrats), total area sampled and sampling site would all affect such data. Nevertheless, our results do indicate healthy populations of hard corals on Two-Mile Reef in 2010. This apparent stability of coral communities in Sodwana Bay may imply that they are relatively resilient, because these reefs have largely escaped the bleaching and disease that have caused marked declines in coral cover on tropical Indo-Pacific reefs over the same period (Bellwood et al. 2004; Schleyer et al. 2008). However, the most recent bleaching event in 2005 in southern Africa highlights that these high-latitude reefs are not immune, with extensive bleaching (up to 39\% of colonies) in localised areas of the Maputaland coastline, northern KwaZulu-Natal, caused by fluctuating sea temperatures and solar radiation (Ruiz Sebastián et al. 2009), although there is no information on how much of the bleached coral died. The results of the current study were similar to those of Riegl et al. (1995) and Riegl and Riegl (1996), who reported that scleractinian corals occupied slightly more space than alcyonaceans (soft corals) and both exceeded sponges and other invertebrates. Macroalgae were not mentioned in their studies. Riegl and Riegl (1996) specifically reported that 


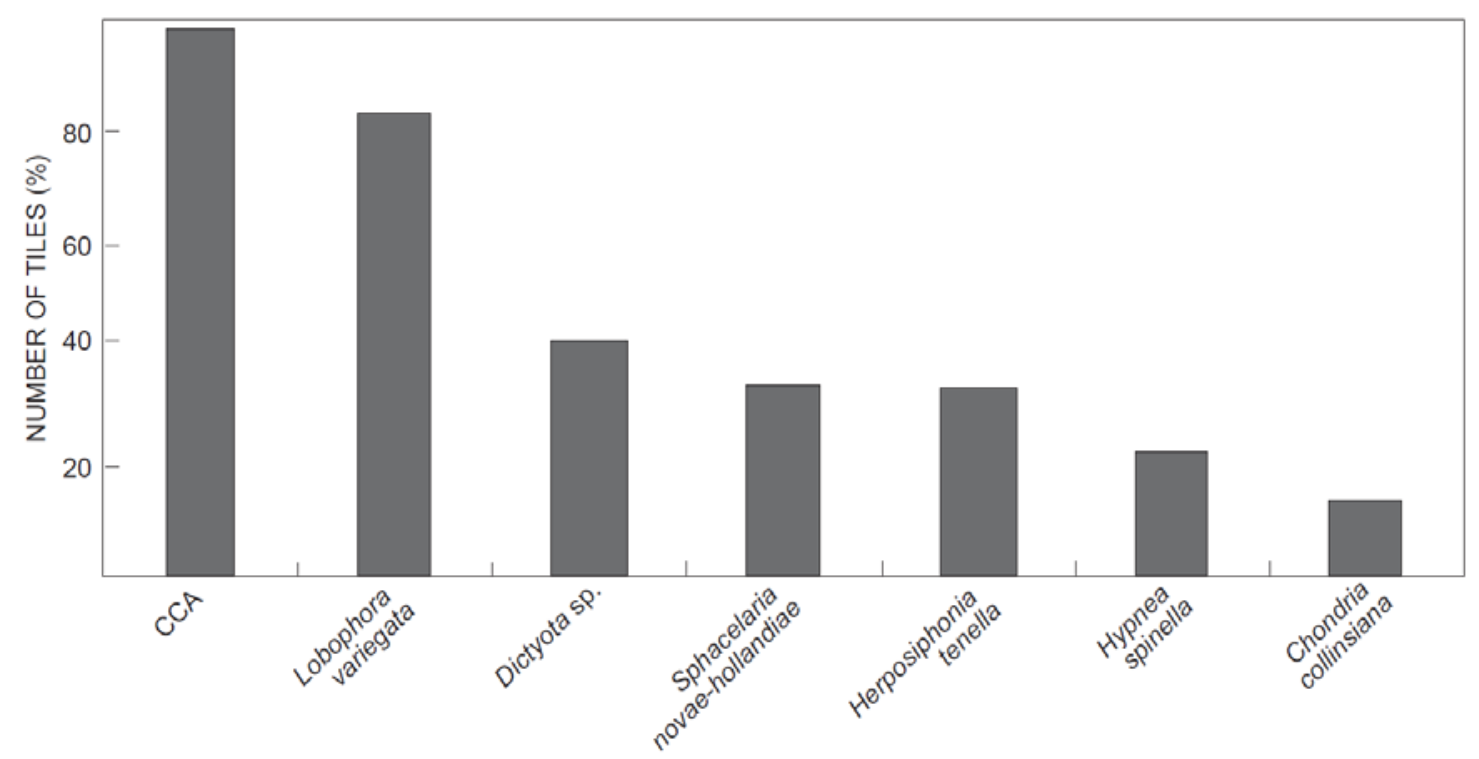

Figure 9: Overall percentage frequency for the seven most common macroalgal taxa (mean cover $>10 \%$ ), including crustose coralline algae (CCA), on all tile types

Table 4: Mean Braun-Blanquet cover scores for the seven most common macroalgal taxa, including crustose coralline algae, for each tile type and significance of the difference between tile types. Mean refers to cover scores over all tile types

\begin{tabular}{|c|c|c|c|c|c|}
\hline Algal taxon & Treated (SD) & Marble (SD) & Ceramic (SD) & Significance & Mean \\
\hline Crustose coralline algae & $3.04(0.98)$ & $3.58(1.05)$ & $2.50(0.97)$ & $*$ & 3.05 \\
\hline Dictyota sp. & $0.73(1.01)$ & $0.87(1.06)$ & $0.69(1.06)$ & ns & 0.76 \\
\hline Herposiphonia tenella & $0.56(0.92)$ & $0.58(1.06)$ & $0.73(1.07)$ & ns & 0.39 \\
\hline Hypnea spinella & $0.42(1.08)$ & $0.22(0.42)$ & $0.33(0.67)$ & ns & 0.33 \\
\hline Chondria collinsiana & $0.07(0.25)$ & $0.13(0.34)$ & $0.20(0.40)$ & ns & 0.13 \\
\hline
\end{tabular}

${ }^{*}=p<0.001 ; \mathrm{ns}=$ not significant

Two-Mile Reef was clearly dominated by soft corals and low-growing massive hard corals. During the 2005 warm-water anomaly in the southern Indian Ocean, coral bleaching reached unprecedented levels (McClanahan et al. 2007) and resulted in a significant shift in abundance of corals and benthic algae on the high-latitude reefs. The cover of dead corals found at our study site in 2010 was $23.1 \%$, but there are no earlier data from which to infer a trend. As for causes of coral mortality, scleractinian taxa at Sodwana (the digitate coral Stylophora and the plate coral Montipora) are reported to be very susceptible to bleaching (Celliers and Schleyer 2002; Floros et al. 2004), but make up a small percentage of total coral cover (e.g. Schleyer et al. 2008). The important point is that our results showed that all dead corals were colonised by macroalgae. Rapid colonisation of corals by algae after environmental disturbances is a general phenomenon that has been documented following mechanical injuries (Glynn 1990) and bleaching events (Glynn 1993; Hoegh-Guldberg 1999).

\section{Algal colonisation on natural substrata}

This study provides the first quantitative description of the composition and abundance of species comprising the macroalgal community on digitate coral, brain coral, plate coral and hard substrata of Two-Mile Reef. The epilithic and epizoic algal communities were characterised by a high incidence of 'rare' species, as is common of tropical systems 
elsewhere. Stuercke and McDermid (2004) found that $60 \%$ of the Hawaiian shallow subtidal turfs were rare taxa, based on methods that fundamentally measured cover. Scott and Russ (1987) considered 63\% of the epilithic algal community of the central Great Barrier Reef to be rare species, individually comprising $<7 \%$ of the canopy cover. On Two-Mile Reef, $91 \%$ of the species individually comprised $<7 \%$ of the percentage cover. A considerable number of algal genera observed on the reef are common components of algal communities in tropical parts of the world. Of the 16 macroalgal genera described by Scott and Russ (1987) as being widespread across several coral reef areas, such as the Caribbean, the Great Barrier Reef, Hawaii and Guam, 12 were common at Two-Mile Reef.

African Journal of Marine Science 2016, 38(3): 303-316

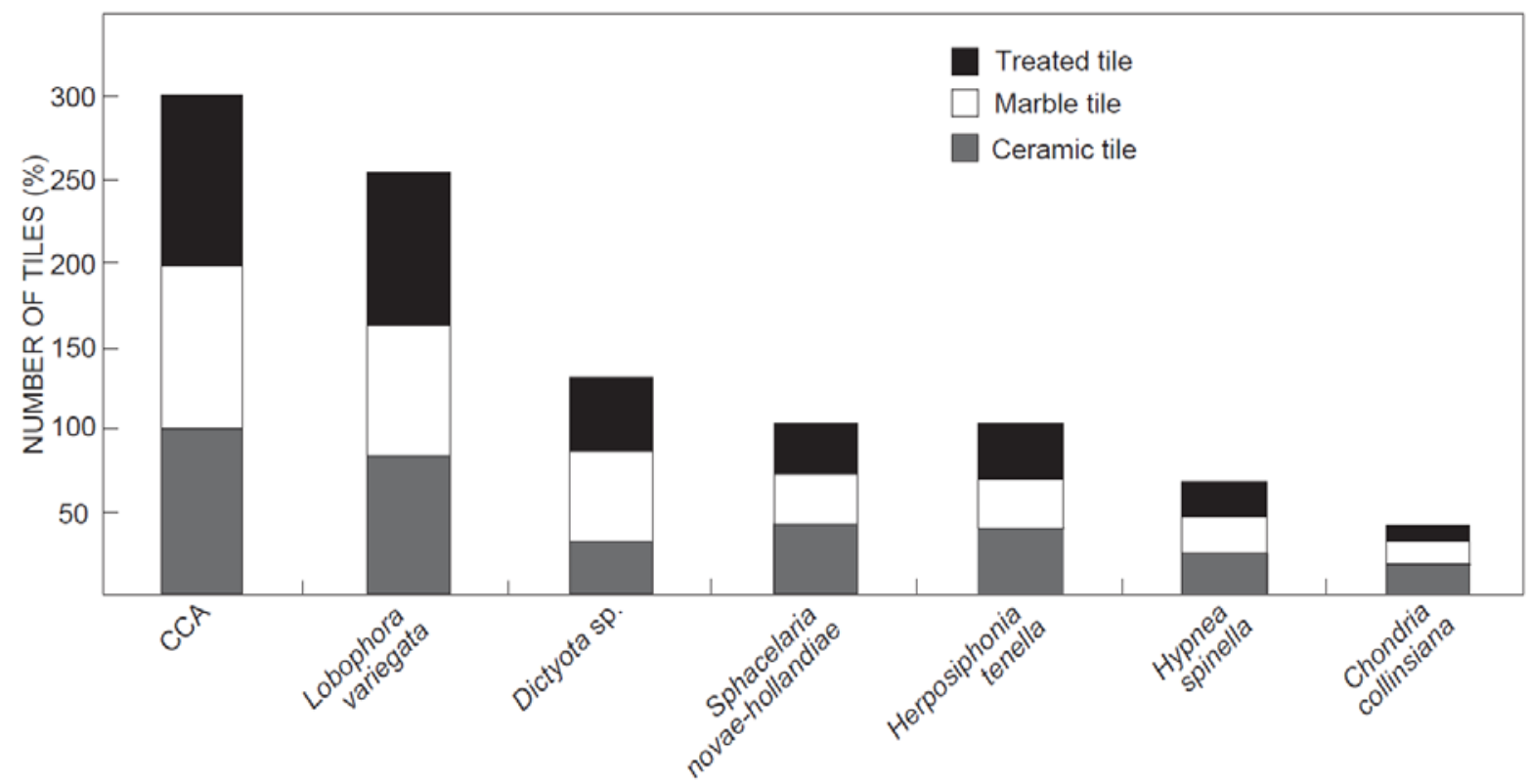

Figure 10: Cumulative percentage frequencies across tile types for the seven most common macroalgal taxa (mean $>6 \%$ ), including crustose coralline algae

These included Centroceras, Ceramium, Gelidiella, Herposiphonia, Hypnea, Jania, Laurencia, Polysiphonia (Rhodophyta), Cladophora (Chlorophyta), Dictyota, Sphacelaria (Phaeophyta) and Lyngbya (Cyanobacteria). Only six of the 95 taxa (including crustose coralline algae as a group) were classed as common, abundant or dominant regarding occurrence; two of these, the dictyotalean L. variegata and the non-geniculate corallines, accounted for most of the algal cover on all the different substrata.

\section{Seasonal variability}

The macroalgal communities of Two-Mile Reef showed no marked seasonal dynamics. Lüning (1990) and Ateweberhan et al. (2006) described temperature as one of the primary factors controlling macroalgal growth in high-latitude reefs, because algal growth was stimulated during low water temperatures in winter. Yet the current study could not identify significant seasonal changes in macroalgal communities on natural substrata, a finding that is inconsistent with previous studies. For example, studies on tropical Atlantic and Caribbean 
macroalgae have found that different algal groups dominated their respect ive communities at distinct times of the year (Lirman and Biber 2000; Diaz-Pulido and Garzón-Ferreira 2002; Ferrari et al. 2012). In the Caribbean, the abundance of Dictyota spp. was positively correlated with water temperature and highest during the summer (Lirman and Biber 2000; Ferrari et al. 2012), whereas L. variegata was more abundant during winter (Ferrari et al. 2012). Similar seasonal changes in L. variegata have been observed on the Great Barrier Reef by Diaz-Pulido et al. (2009).

\section{Community variation on different substrata}

The fact that L. variegata is the dominant macroalgal low-growing species in the subtidal of Sodwana Bay is consistent with its known abundance worldwide in many tropical to warmtemperate areas (Womersley 1967; Littler and Littler 2000). The abundance of L. variegata along Two-Mile Reef fits with the expected pattern of dominance of dictyotalean assemblages along the Maputaland region (Bolton et al. 2004). The dominance of L. variegata may be partly explained by the algal defence mechanisms that contribute to their persistence against herbivory. Two common macroalgal defence mechanisms are escape and deterrence (Hay and Fenical 1988), which may be used by L. variegata. Diaz-Pulido et al. (2009) reported that L. variegata under normal or undisturbed conditions is not able to grow beyond the base of the branches, on account of competitive inhibition by the corals. However, we frequently observed L. variegata growing upwards from the base and between the branches of most digitate coral colonies on Two-Mile Reef. The high abundance of L. variegata on branching substrata suggests that it was released from space competition with the corals, because of the bleaching mortality on the reef. Additionally, the high cover of L. variegata further suggests that the branching coral framework provides an 'escape' from herbivores. The second mode of defence that may have contributed to the high cover of L. variegata is deterrence. The deterrence of herbivores by L. variegata is achieved primarily through the use of allelochemicals (Targett and Arnold 1998) and its exhibition of different morphological forms (ruffled, decumbent and encrusting; Coen and Tanner 1989). In the current study, encrusting and decumbent forms of L. variegata were commonly found along the reef. Coen and Tanner (1989) suggest that the decumbent form may be among the least palatable tropical algae for both crabs and fish, whereas the encrusting form appears to be less susceptible to grazing, because of its tightly adhering (encrusting) habit. There are no previous observations of such extensive growths of Lobophora variegata, or indeed any single species of fleshy macroalga, on Two-Mile Reef. Our data support the observations of Coen and Tanner (1989), Bennett et al. (2010) and Sangil et al. (2011) that L. variegata forms a dynamic component of many coral reef communities. However, it should be noted that L. variegate may in fact comprise more than one species, because molecular studies of New Caledonia Lobophora detected 31-39 species where only four were previously recognised (Vieira et al. 2014) and molecular evidence suggests the presence of several species in this complex in South Africa (C Vieira and O De Clerck, Ghent University, Belgium, pers. comm.). We noted some morphological variations among specimens on the reef (e.g. semi-creeping vs erect), but many individuals were intermediate between these forms and in the absence of better taxonomic information we regarded them all as one species. The similarity between seaweed species on the different types of substrata, including the types of 
coral, indicates that seaweeds will recruit onto any hard substratum on these reefs. In a system like this, where there are many species present and scattered throughout the reef, with few dominants, this is perhaps not surprising. This patchy distribution pattern with numerous rare species (as found on Hawaiian reefs by Stuercke and McDermid 2004) suggests that opportunistic recruitment is the main determinant of community composition. There do not appear to be any other studies that have investigated algal growth on different morphological types of dead coral.

\section{Algal colonisation of artificial substrata}

The most important outcome of this aspect of the study was that the nature of the artificial substratum had little influence on the recruitment success of coral reef macroalgae on TwoMile Reef. In general, variations in the abundance of non-crustose macroalgal recruits among tile types were not significant, notwithstanding significant differences in crustose coralline abundance between ceramic and marble tiles. Earlier researchers have generally found that some crustose coralline algae inhibit the recruitment of algal propagules, either by epithallial shedding or enhanced grazing on the surface of the crustose corallines (Keats et al. 1997; Littler and Littler 1997). These processes could explain the weak negative relationship between non-crustose macroalgal recruits and pretreated ceramic tiles. However, this contrasts markedly with the relatively high cover of L. variegata on the pretreated tiles. Santelices and Varela (1994) found that calcium carbonate facilitated rhizoidal attachment in fleshy macroalgae, perhaps explaining an apparent association between L. variegate and crustose coralline algae. At the end of our experiment, bare tile surfaces had developed epilithic algal communities dominated by filamentous algal turfs, non-geniculate (crustose) corallines and canopy-forming brown algae. The algal communities colonising the settlement tiles in this study showed a similar structure to those of previous studies in the western Indian Ocean (Uku et al. 2000) and Great Barrier Reef (McClanahan 1997). McClanahan (1997) reported that algal turf and coralline algae were dominant on all plates within 150 days following tile placement. He reported that the succession of algae was from algal turf to coralline algae, followed by an increase in calcareous algae and climaxing with an abundance of large canopy-forming brown algal genera, such as Sargassum and Turbinaria. The results of the current study suggest that the sequence of succession was similar, except that calcareous algae never developed greatly on most tiles, in the 6-month study period. Relatively large brown algae, such as L. variegate would appear to be the most abundant space-occupying species at the climax of succession. Fleshy algae, although common on TwoMile Reef, did not grow to any size or abundance on the experimental tiles. This may be because of insufficient time, but is more likely because of the flat shape of the tiles. Flat tiles may not provide the rugosity and associated refuge that is necessary for the development of these species (McClanahan 1997). Rugose ceramic tiles have been suggested to protect algal recruits from dislodgement by herbivore activity and wave action and to increase the tile surface area available for settlement and recruitment (Amsler et al. 1992; Anderson and Underwood 1994). Diaz-Pulido and McCook (2004) found that ceramic tiles with rougher surfaces had significantly more algal recruits than those with smoother surfaces. Among the ceramic and pretreated ceramic tiles in the current study, there was a higher (although not significant) cover abundance of $\mathrm{L}$. variegata compared to the smoother marble tiles. In 
contrast, marble tiles had significantly higher cover of non-geniculate coralline algae. This may reflect the outcome of competition with other macroalgae, the adherence of which may have been weakened by the smooth marble surface. Although it is not possible to compare directly recruitment on natural substrata and artificial tiles in a factorial analysis, it is noteworthy that abundance of non-geniculate coralline algae was lower on natural substrata than on artificial substrata. Whether this resulted from physical or chemical differences in the substrata is unclear, although flat surfaces provide little refuge and are consequently more susceptible to grazing disturbance. Consequently, roaming herbivorous fish, like some surgeonfish and parrotfish, may promote coralline recruitment by cropping the easily accessible and nutritious turfs.The current study is the first to investigate macroalgal colonisation of dead corals and other substrata on these high-latitude eastern Indian Ocean coral reefs and demonstrates an essentially indiscriminate settlement of macroalgae on hard surfaces, including any types of dead coral. It also provides quantitative baseline information on algal diversity and substratum types that should be useful in future studies of these systems, particularly considering the increasing threats to coral systems worldwide. Acknowledgements - This study was conducted under the auspices of the African Coelacanth Ecosystem Programme (ACEP) as part of the project 'Integrated biodiversity and process study of African coelacanths and their ecosystems' led by Prof. Anthony Booth (Rhodes University). We thank the Department of Biological Sciences, University of Cape Town, for funding and equipment and the South African National Research Foundation (NRF) for their financial support. We thank the Oceanographic Research Institute in Durban for the opportunity to examine the algae on their experimental setup. The Department of Agriculture, Forestry and Fisheries supported the participation of RJA. We are grateful to Ezemvelo KwaZulu-Natal Wildlife and the iSimangaliso Wetland Park for permission to work and collect at Sodwana. We also thank Elizabeth van der Merwe for her help in the University of the Western Cape laboratory. We extend warm thanks to Chris Boothroyd for diving and other technical assistance and to the staff of Triton Diving for their hospitality and excellent diving support. Two anonymous reviewers are thanked for very helpful comments on an earlier draft of the manuscript. 


\section{References}

Adjeroud M, Michonneau F, Edmunds PJ, Chancerelle Y, Lison de Loma T, Penin L et al. 2009. Recurrent disturbances, recovery trajectories and resilience of coral assemblages on a South Central Pacific reef. Coral Reefs 28: 775- 780.

Amsler CD, Reed DC, Neushul M. 1992. The microclimate inhabited by macroalgal propagules. British J ournal of Phycology 27: 253- 270.

Anderson MJ, Underwood AJ. 1994. Effects of substratum on the recruitment and development of an intertidal estuarine fouling assemblage. J ournal of Experimental Marine Biology and Ecology 184: 217- 236.

Anderson RJ, McKune C, Bolton JJ, De Clerck O, Tronchin E. 2005. Patterns in subtidal seaweed communities on coral-dominated reefs at Sodwana Bay on the KwaZuluNatal coast, South Africa. African J ournal of Marine Science 27: 529- 537.

Ateweberhan M, Bruggemann JH, Breeman AM. 2006. Effects of extreme seasonality on community structure and functional group dynamics of coral reef algae in the southern Red Sea (Eritrea). Coral Reefs 25: 391- 406.

Bellwood DR, Hughes TP, Folke C, Nyström M. 2004. Confronting the coral reef crisis. Nature 429: 827- 833.

Bennett S, Vergés A, Bellwood DR. 2010. Branching coral as a macroalgal refuge in a marginal coral reef system. Coral Reefs 29: 471- 480.

Bolton JJ, Leliaert F, De Clerck O, Anderson RJ, Stegenga H, Engledow HE, Coppejans E. 2004. Where is the western limit of the tropical Indian Ocean seaweed flora? An analysis of intertidal seaweed biogeography on the east coast of South Africa. Marine Biology 144: 51- 59.

Celliers L, Schleyer MH. 2002. Coral bleaching on high latitude marginal reefs at Sodwana Bay, South Africa. Marine Pollution Bulletin 44: 1380- 1387.

Celliers L, Schleyer MH. 2008. Coral community structure and risk assessment of high latitude reefs at Sodwana Bay, South Africa. Biodiversity and Conservation 17: 30973117.

Coen LD, Tanner CE. 1989. Morphological variation and differential susceptibility to herbivory in the tropical brown alga Lobophora variegata. Marine Ecology Progress Series 54: 287- 298.

De Clerck O, Bolton JJ, Anderson RJ, Coppejans E. 2005. Guide to the seaweeds of KwaZulu-Natal. Scripta Botanica Belgica Vol.33. Meise: National Botanic Garden of Belgium.

Diaz-Pulido G, Garzón-Ferreira J. 2002. Seasonality of algal assemblages on upwellinginfluenced coral reefs in the Colombian Caribbean. Botanica Marina 45: 284- 292.

Diaz-Pulido G, McCook LJ . 2002. The fate of bleached corals: patterns and dynamics of algal recruitment. Marine Ecology Progress Series 232: 115- 128.

Diaz-Pulido G, McCook LJ. 2004. Effects of live coral, epilithic algal communities and substrate type on algal recruitment. Coral Reefs 23: 225- 233.

Diaz-Pulido G, McCook LJ , Dove S, Berkelmans R, Roff G, Kline DI et al. 2009. Doom and boom on a resilient reef: climate change, algal overgrowth and coral recovery. PLoS ONE 4:e5239. 
Emslie MJ, Pratchett MS, Cheal AJ, Osborne K. 2010. Great Barrier Reef butterflyfish community structure: the role of shelf position and benthic community type. Coral Reefs 29:705- 715.

Ferrari R, Gonzalez-Rivero M, Ortiz JC, Mumby PJ. 2012. Interaction of herbivory and seasonality on the dynamics of Caribbean macroalgae. Coral Reefs 31: 683- 692.

Floros CD, Samways MJ, Armstrong B. 2004. Taxonomic patterns of bleaching within a South African coral assemblage. Biodiversity and Conservation 13: 1175- 1194.

Fong P, Lirman D. 1995. Hurricanes cause population expansion of the branching coral Acropora palmata. Marine Ecology 16: 317- 335.

Glynn PW. 1990. Coral mortality and disturbances to coral reefs in the tropical eastern Pacific. In Glynn PW (ed.), Global consequences of the 1982- 83 El Niño southern oscillation. Elsevier Oceanography Series, Vol. 52. Amsterdam: Elsevier. pp 55- 126.

Glynn PW. 1993. Coral reef bleaching: ecological perspectives. Coral Reefs 12: 1- 17.

Harriott VJ , Banks SA. 2002. Latitudinal variation in coral communities in eastern Australia: a qualitative biophysical model of factors regulating coral reefs. Coral Reefs 21: 8394.

Hart J R. 2012. Coral recruitment on a high-latitude reef at Sodwana Bay, South Africa: research methods and dynamics. MSc thesis, University of KwaZulu-Natal, Durban, South Africa.

Hay ME, Fenical W. 1988. Marine plant-herbivore interactions: the ecology of chemical defence. Annual Review of Ecology, Evolution and Systematics 19: 111- 145.

Hoegh-Guldberg O. 1999. Climate change, coral bleaching and the future of the world's coral reefs. Marine and Freshwater Research 50: 839- 866.

Hoegh-Guldberg O, Mumby PJ, Hooten AJ, Steneck RS, Greenfield P. 2007. Coral reefs under rapid climate change and ocean acidification. Science 318: 1737- 1742.

Hughes TP. 1994. Catastrophes, phase shifts, and large-scale degradation of a Caribbean coral reef. Science 265: 1547- 1551.

Hughes TP, Baird AH, Bellwood DR, Card M, Connolly SR, Folke C et al. 2003. Climate change, human impacts, and the resilience of coral reefs. Science 301: 929- 933.

J aasund E. 1976. Intertidal seaweeds in Tanzania: a field guide. Tromsø: University of Tromsø.

J ordan IE, Samways MJ . 2001. Recent changes in coral assemblages of a South African coral reef, with recommendations for long-term monitoring. Biodiversity and Conservation 10: 1027- 1037.

Keats DW, Knight MA, Pueschel CM. 1997. Antifouling effects of epithallial shedding in three crustose coralline algae (Rhodophyta, Corallinales) on a coral reef. Journal of Experimental Marine Biology and Ecology 213: 281- 293.

Lepš J , Hadincová V. 1992. How reliable are our vegetation analyses? J ournal of Vegetation Science 3: 119- 124.

Lirman D, Biber P. 2000. Seasonal dynamic of macroalgal communities of the northern Florida reef tract. Botanica Marina 43: 305- 314.

Littler DS, Littler MM. 2000. Caribbean reef plants. An identification guide to the reef plants of the Caribbean, Bahamas, Florida and Gulf of Mexico. Washington: Offshore Graphics. 
Littler MM, Littler DS. 1997. Disease induced mass mortality of crustose coralline algae on coral reefs provides rationale for the conservation of herbivorous fish stocks. In: Lessios HA, Macintyre IG (eds), Proceedings of the 8th International Coral Reef Symposium, Vol. 1, 24-29 June 1996. Republic of Panama: Smithsonian Tropical Research Institute. pp 719- 724.

Lüning K. 1990. Seaweeds. Their environment, biogeography, and ecophysiology. New York: Wiley.

Maneveldt GW, van der Merwe E. 2012. Heydrichia cerasina sp. nov. (Sporolithales, Corallinophycidae, Rhodophyta) from the southernmost tip of Africa. Phycologia 51: $11-21$.

McClanahan TR. 1997. Primary succession of coral-reef algae: differing patterns on fished versus unfished reefs. J ournal of Experimental Marine Biology and Ecology 218: 77102.

McClanahan TR, Ateweberhan M, Graham NAJ, Wilson SK, Ruiz Sebastián C, Guillaume MMM, Bruggemann J H. 2007. Western Indian Ocean coral communities: bleaching responses and susceptibility to extinction. Marine Ecology Progress Series 337: 1- 13.

McCook LJ . 1999. Macroalgae, nutrients and phase shifts on coral reefs: scientific issues and management consequences for the Great Barrier Reef. Coral Reefs 18: 357- 367.

McManus JW, Polsenberg J F. 2004. Coral-algal phase shifts on coral reefs: ecological and environmental aspects. Progress in Oceanography 60: 263- 279.

Mumby PJ . 2009. Phase shifts and the stability of macroalgal communities on Caribbean coral reefs. Coral Reefs 28: 761- 773.

Mumby PJ, Foster NL, Fahy EAG. 2005. Patch dynamics of coral reef macroalgae under chronic and acute disturbance. Coral Reefs 24: 681- 692.

Oliveira EC, Österland K, Mtolera MSP. 2005. Marine plants of Tanzania: a field guide to the seaweeds and seagrasses. Stockholm: Botany Department, Stockholm University.

Pandolfi J M, Jackson J BC, Baron N, Bradbury RH, Guzmán HM, Hughes TP et al. 2005. Are U.S. coral reefs on the slippery slope to slime? Science 307: 1725- 1726.

Ramsay PJ, Cooper JAG, Wright CI, Mason TR. 1989. The occurrence and formation of ladderback ripples in subtidal, shallow-marine sands, Zululand, South Africa. Marine Geology 86: 229- 235.

Ramsay PJ , Mason TR. 1990. Development of a type zoning model for Zululand coral reefs, Sodwana Bay, South Africa. J ournal of Coastal Research 6: 829- 852.

Riegl B, Piller WE. 2003. Possible refugia for reefs in times of environmental stress. International J ournal of Earth Sciences 92: 520- 531.

Riegl B, Riegl A. 1996. Studies on coral community structure and damage as a basis for zoning marine reserves. Biological Conservation 77: 269- 277.

Riegl B, Schleyer MH, Cook PJ, Branch GM. 1995. Structure of Africa's southernmost coral communities. Bulletin of Marine Science 56: 679-691.

Roberts MJ, Ribbink AJ, Morris T, van den Berg MA, Engelbrecht DC, Harding RT. 2006. Oceanographic environment of the Sodwana Bay coelacanths (Latimeria chalumnae), South Africa. South African J ournal of Science 102: 435- 443.

Rogers CS, Garrison V, Grober-Dunsmore R. 1997. A fishy story about hurricanes and herbivory, seven years of research on a reef in St. J ohn, U.S. Virgin Islands. In: Lessios 
HA, Macintyre IG (eds), Proceedings of the 8th International Coral Reef Symposium, Vol. 1, 24- 29 June 1996. Republic of Panama: Smithsonian Tropical Research Institute. pp 555- 560.

Ruiz Sebastián C, Sink KJ , McClanahan TR, Cowan DA. 2009. Bleaching response of corals and their Symbiodinium communities in southern Africa. Marine Biology 156: 20492062.

Sangil C, Sansón M, Afonso-Carrillo J. 2011. Spatial variation patterns of subtidal seaweed assemblages along a subtropical oceanic archipelago: thermal gradient vs. herbivore pressure. Estuarine, Coastal and Shelf Science 94: 322- 333.

Santelices B, Varela D. 1994. Abiotic control of reattachment in Gelidium chilense (Montagne) Santelices and Montalva (Gelidiales; Rhodophyta). Journal of Experimental Marine Biology and Ecology 177: 145- 155.

Schleyer MH. 1999. A synthesis of KwaZulu-Natal coral research. Special Publication No. 5. Durban: Oceanographic Research Institute.

Schleyer MH, Kruger A, Celliers L. 2008. Long-term community changes on high-latitude coral reefs in the Greater St Lucia Wetland Park, South Africa. Marine Pollution Bulletin 56: 493- 502.

Scott FJ, Russ GR. 1987. Effects of grazing on species composition of the epilithic algal community on coral reefs of the central Great Barrier Reef. Marine Ecology Progress Series 39: 293- 304.

Stegenga H, Bolton JJ , Anderson RJ . 1997. Seaweeds of the South African west coast. Cape Town: Bolus Herbarium, University of Cape Town.

Stuercke B, McDermid KJ . 2004. Variation in algal turf species composition and abundance on two Hawaiian shallow subtidal reefs. Cryptogamie Algologie 25: 353- 365.

Targett MN, Arnold TM. 1998. Predicting the effects of brown algal phlorotannins on marine herbivores in tropical and temperate oceans. J ournal of Phycology 34: 195- 205.

Titlyanov EA, Titlyanova TV, Chapman DJ. 2008. Dynamics and patterns of algal colonization on mechanically damaged and dead colonies of the coral Porites lutea. Botanica Marina 51: 285- 296.

Tribble GW, Randall RH. 1986. A description of the high latitude shallow water coral communities of Miyake-jima, J apan. Coral Reefs 4: 151- 159.

Tsuda RT, Abbott IA. 1985. Collection, handling, preservation, and logistics. In: Littler MM, Litter SS (eds), Handbook of phycological methods. Ecological field methods: macroalgae. Cambridge: Cambridge University Press. pp 67- 86.

Uku J, Ndirangu S, Muthama C. 2000. Trends in the distribution of macroalgae in a bleached Kenyan reef ecosystem. In: Lindén O, Souter D, Wilhelmsson D, Obura D (eds), Coral reef degradation in the Indian Ocean. Stockholm: CORDIO [Coral Reef Degradation in the Indian Ocean]. pp 61- 69.

Vieira C, D’hondt S, De Clerck O, Payri CE. 2014. Toward an inordinate fondness for stars, beetles and Lobophora? Species diversity of the genus Lobophora (Dictyotales, Phaeophyceae) in New Caledonia. J ournal of Phycology 50: 1101- 1119.

Vroom PS, Braun CL. 2010. Benthic composition of a healthy subtropical reef: baseline species-level cover, with an emphasis on algae, in the Northwestern Hawaiian Islands. PLoS ONE 5: e9733. 
Wilkinson C. 2002. Status of coral reefs of the world: 2002. Townsville: Australian Institute of Marine Science.

Wismer S, Hoey AS, Bellwood DT. 2009. Cross-shelf benthic community structure on the Great Barrier Reef: relationships between macroalgal cover and herbivore biomass. Marine Ecological Progress Series 376: 45- 54.

Womersley HBS. 1967. A critical survey of the marine algae of southern Australia. II. Phaeophyta. Australian J ournal of Botany 15: 189- 279.

Worm B, Chapman ARO. 1998. Relative effects of elevated grazing pressure and competition from a red algal turf on two post-settlement stages of Fucus evanescens C. Ag. J ournal of Experimental Marine Biology and Ecology 220: 247- 268. 